\title{
Quercetin as a Protease (á-Chymotrypsin) Inhibitor
}

\author{
G. B. Bajracharya ${ }^{1}$ and D. B. Thapa ${ }^{2}$ \\ ${ }^{1}$ Nepal Academy of Science and Technology (NAST), Khumaltar, Lalitpur \\ ${ }^{2}$ Tri-Chandra Multiple Campus, Ghantaghar, Tribhuvan University \\ e-mail: ganbajracharya@yahoo.com
}

\begin{abstract}
Quercetin, isolated from the skin of red onion bulb, was methylated to afford quercetin 3,3',4',7-tetramethyl ether in 83.3\% yield. Quercetin has displayed á-chymotrypsin inhibitory effect ( $\mathrm{IC}_{50}=88.9 \pm 2.5 \mu \mathrm{g} / \mathrm{ml}$ ), $\mathrm{DPPH}$ free radical scavenging activity $\left(\mathrm{IC}_{50}=14.87 \mathrm{ig} / \mathrm{ml}\right)$ and ferric reducing power $\left(\mathrm{EC}_{1}=112.94 \mathrm{iM} /\right.$ equivalent to $\left.1 \mathrm{mM} / \mathrm{FeSO}_{4} .7 \mathrm{H}_{2} \mathrm{O}\right)$, whereas no enhancement of these biological activities was observed using its tetramethyl ether derivative.
\end{abstract}

Key words: Allium cepa, á-chymotrypsin, DPPH assay, FRAP assay, quercetin 3,3',4',7-tetramethyl ether

\section{Introduction}

Protease is a large family of enzymes, which catalyses the hydrolysis of proteins. Proteases not only catalyse the destruction of cellular proteins and peptides, but also help in the replication of some viruses by cleaving their precursor proteins. Proteases of HCV (NS3 protease) and HIV are key enzymes that accelerate the replication of viruses and are thus recognised as valid targets for antiHCV and anti-HIV drugs. The excessive activity of proteases may cause several diseases such as pulmonary emphysema, arthritis, pancreatitis etc. Proteases also help in tumour growth (Patick \& Potts 1998).

$\alpha$-Chymotrypsin (EC 3.4.21.1), a serine protease mainly secreted from pancreas, catalyses the breakdown of polypeptide and proteins. This enzyme not only digests proteins from foods but also catalyses the degradation of body's own tissues in uncontrolled manner in diseases such as pancreatitis and cirrhosis (Wilcox 1970). $\alpha$ Chymotrypsin activates epithelial sodium channel (EnaC) by proteolytic cleavage which results in cystic fibrosis (Rauh et al. 2010). Chymotrypsin along with cathepsin is responsible for the cleavage of interleukin 1- $\beta$ (IL-1 $\beta$ ) precursor into functional active IL-1â, which causes inflammatory arthritis (Stehlik 2009). Therefore, inhibition of $\alpha$-chymotrypsin is important for treatment of several diseases.

Research on flavonoids has become popular since these polyphenols are ubiquitous in nature and are potential for various uses. Quercetin (1) is one of the most potent antioxidants among flavonoids and has displayed antiviral, antibacterial, anticarcinogenic and anti-inflammatory effects (Materska 2008, Bohm 1998). It is estimated that up to $1 \mathrm{~g}$ of flavonoid per day is taken by human from the dietary sources and quercetin derivatives cover $70 \%$ of the value (Formica \& Regelson 1995, Hertog et al. 1993). In food, quercetin occurs in aglycone or bounded form with sugars, phenolic acids, alcohols etc. After ingestion, quercetin derivatives are hydrolysed in the gastrointestinal tract into aglycone and then absorbed and metabolised (Scalbert \& Williamson 2000, Walle 2004). Despite, quercetin is a major natural constituent we intake, the impact of quercetin on human health and research on its bioactivity are still at the developmental stage. Recently, we have commenced a research program to study the quantitative structure-activity relationship (QSAR) of quercetin derivatives. Herein, we have isolated quercetin (1) from the onion skin and its tetramethyl ether derivative (2) was synthesized. These compounds were used to evaluate protease inhibition effect 
( $\alpha$-Chymotrypsin assay) as well as antioxidant capacity (DPPH and FRAP assays).

\section{Methodology \\ General}

Analytical thin layer chromatography (TLC) was performed on $0.2 \mathrm{~mm}$ pre-coated plate Kieselgel $60 \mathrm{~F}_{254}$. Melting point was recorded using electrical melting point apparatus (OGAWA SEIKI Co. Ltd., Tokyo). NMR spectra in $\mathrm{CD}_{3} \mathrm{OD}$ were recorded on Advance AV-500 at H.E.J. Research Institute of Chemistry, University of Karachi, Karachi, Pakistan. Spectramax M2, Molecular Devices was used in the measurement of enzyme inhibition and $6715 \mathrm{UV} / \mathrm{Vis}$ Spectrophotometer JENWAY was used for other spectrophotometry.

\section{Isolation of quercetin (1)}

Dried skin of red onion bulb (Allium cepa) (500 g), collected from a local shop, was extracted with $\mathrm{MeOH}$ (3 l) using a Soxhlet extractor. The methanolic extract was concentrated using a rotary evaporator under reduced pressure. To the obtained concentrate was added distilled water $\left(300 \mathrm{ml}\right.$ ) and extracted with $\mathrm{Et}_{2} \mathrm{O}$ $(500 \mathrm{ml} \times 3)$. Organic solvent was evaporated under vacuum to obtain a solid residue (5 g). This residue was fractionated by column chromatography on silica gel (60-120 mesh) with an increasing polarity gradient of EtOAc/MeOH (from 100:0 to 80:20) collecting 17 fractions of $100 \mathrm{ml}$. Fractions (F1-F7) were found to possess a distinct yellow spot with $\mathrm{R}_{\mathrm{f}}=0.88$ together with other spots on TLC (EtOAc/MeOH, 9:1), which were combined. The pooled fraction was concentrated to obtain a yellow residue $(2 \mathrm{~g})$. This residue was further purified on silica gel column eluting with hexane/ EtOAc (from 10:1 to 10:9) to afford a chromatographically pure yellow compound, which after recrystallisation in $\mathrm{MeOH}$ gave crystals of quercetin (3,3',4',5,7-pentahydroxy flavone; 2-(3,4dihydroxyphenyl)-3,5,7-trihydroxy-4H-chromen-4-one (1), $500 \mathrm{mg}, 0.1 \%)$. UV-Vis $\lambda_{\max } \mathrm{nm}:(\mathrm{MeOH}) 232,255$, 372; $(\mathrm{MeOH}+\mathrm{NaOAc}) 232,272,377 ;(\mathrm{MeOH}+\mathrm{NaOAc}$ $\left.+\mathrm{H}_{3} \mathrm{BO}_{3}\right)$ 230, 262, 386; $\left(\mathrm{MeOH}+\mathrm{AlCl}_{3}\right) 232,273,452$; $\left(\mathrm{MeOH}+\mathrm{AlCl}_{3}+\mathrm{HCl}\right.$ ) 229, 271, 359 (inf), 429; (MeOH $+\mathrm{NaOH}$ ) 230, 288, 328 (inf), 425. ${ }^{1} \mathrm{H}$ NMR ( $\left.\mathrm{CD}_{3} \mathrm{OD}\right)$ ä ppm: 6.2 (d, $J=1.9 \mathrm{~Hz}, \mathrm{H}-8), 6.42$ (d, $J=1.9 \mathrm{~Hz}, \mathrm{H}-6), 6.9$ (d, $J=8.5 \mathrm{~Hz}, \mathrm{H}-5$ '), 7.56 (dd, $J=2.2,2.2 \mathrm{~Hz}, \mathrm{H}-6^{\prime}$ ), 7.68 (d, $J=2.2 \mathrm{~Hz}, \mathrm{H}-2$ '), 9.33 (s, OH-3'), 9.35 (s, OH-4'), 9.63 (s, OH-3), 10.85 (s, OH-7), 12.49 (s, OH-5). These data are in close agreement with the findings of (Tuladhar and Bajracharya 1999).

\section{Synthesis of quercetin 3,3',4',7-tetramethyl ether (2)}

Dehydration of acetone was carried out in prior by treating with excess of $\mathrm{K}_{2} \mathrm{CO}_{3}$ for overnight followed by filtration and distillation at normal atmospheric pressure.

In a two-necked flask of $50 \mathrm{ml}$ capacity equipped with magnetic stirrer, reflux condenser and $\mathrm{CaCl}_{2}$ guard tube was added $1(0.3 \mathrm{mmol}, 92.2 \mathrm{mg})$ and dehydrated acetone $(12 \mathrm{ml})$. To the stirred reaction mixture was introduced excess of anhydrous $\mathrm{K}_{2} \mathrm{CO}_{3}(1.21 \mathrm{~g})$ and MeI (1.1 ml). After refluxing at 65 ÚC for $5 \mathrm{~h}$, complete consumption of 1 was observed on TLC and the reaction mixture was cooled to room temperature followed by quenching with water $(6 \mathrm{ml})$. The reaction mixture was neutralised by addition of $2 \mathrm{~N} \mathrm{H}_{2} \mathrm{SO}_{4}$ drop wisely and then extracted with EtOAc $(15 \mathrm{ml} \times 3)$, washed with brine, dried with $\mathrm{Na}_{2} \mathrm{SO}_{4}$, filtered and finally concentrated. The residue was purified by column chromatography (200-400 mesh) using an increasing polarity gradient of hexane/EtOAc (from 100:0 to 25:75) to afford quercetin 3,3', 4',7-tetramethyl ether (5-hydroxy-3,3',4',7-tetramethoxy flavone; 2-(3,4dimethoxyphenyl)-5-hydroxy-3,7-dimethoxy-4Hchromen-4-one (2), $90.0 \mathrm{mg}, 83.3 \%$ yield). Melting point $=156-1580^{\circ} \mathrm{C}\left(\right.$ Reported $\left.156-161^{\circ} \mathrm{C}\right)($ Web 1$)$. UV-Vis $\lambda_{\text {max }} \mathrm{nm}$ : (MeOH) 232, 256, 355; (MeOH + NaOAc) 232, 257, 350; $\left(\mathrm{MeOH}+\mathrm{NaOAc}+\mathrm{H}_{3} \mathrm{BO}_{3}\right) 230,256,350$; $\left(\mathrm{MeOH}+\mathrm{AlCl}_{3}\right) 230,272,360,402 ;\left(\mathrm{MeOH}+\mathrm{AlCl}_{3}+\right.$ HCl) 232, 272, 358, 402; (MeOH + NaOH) 231, 284, 374. ${ }^{1} \mathrm{H}$ NMR (CD $\mathrm{OD}$ ) $\delta \mathrm{ppm}$ : 3.82 (s, OMe), 3.89 (s, OMe), 3.917 (s, OMe), 3.924 (s, OMe), 4.53 (s, OH-5, interchangeable), 6.35 (d, $J=2.0 \mathrm{~Hz}, \mathrm{H}-8$ ), 6.66 (d, $J=$ $2.0 \mathrm{~Hz}, \mathrm{H}-6), 7.12$ (d, $J=8.5 \mathrm{~Hz}, \mathrm{H}-2$ '), 7.74 (d, $J=2.0 \mathrm{~Hz}$, H-5'), 7.78 (dd, $J=2.0,8.5 \mathrm{~Hz}, \mathrm{H}-6$ '). The ${ }^{1} \mathrm{H}$ NMR data are in close agreement with the literature (Yoshioka et al. 2004).

\section{á-Chymotrypsin assay}

The inhibitory activity of á-chymotrypsin was performed in $50 \mathrm{mM}$ Tris-HCl buffer $\mathrm{pH} 7.6$ with $10 \mathrm{mM}$ $\mathrm{CaCl}_{2}$ (Choudhary et al. 2011). The enzyme $\alpha$ chymotrypsin (12 units/ml prepared in the buffer) with the $0.5 \mathrm{mM}$ sample prepared in DMSO, was incubated at $30^{\circ} \mathrm{C}$ for $25 \mathrm{~min}$. The reaction was initiated by the 
addition of the chromogenic substrate, $N$-succinyl-Lphenylalanine-p-nitroaniline (SPpNA; $0.4 \mathrm{mM}$ final concentration prepared in the buffer). The change in absorbance by release of $p$-nitroanilide was continuously monitored at $410 \mathrm{~nm}$. The positive control without test compound was replaced by DMSO (final concentration 7\%). The percentage of inhibition based upon initial velocity and calculated as:

$\%$ Inhibition $=100-($ minus $)\left(\mathrm{OD}_{\text {sample }} / \mathrm{OD}_{\text {control }}\right) \times 100$

$\mathrm{IC}_{50}$ value (Inhibition of enzymatic hydrolysis of the substrate SPpNA by 50\%) were determined by monitoring the inhibition value by the increasing the concentration of the test compounds. These $\mathrm{IC}_{50}$ values were calculated by using EZ-Fit enzyme kinetics program (Perellela Scientific, Inc., Amherst, Mars, USA).

\section{2,2-Diphenyl-1-picrylhydrazyl (DPPH) assay}

The DPPH assay was carried out according to the reported method (Brand-Williams et al. 1995). To 0.5 $\mathrm{ml}$ of the solution of test compounds prepared in different concentrations (5, 10, 15, 20 and $25 \mu \mathrm{g} / \mathrm{ml}$ in methanol) was added $0.1 \mathrm{mM}$ methanolic DPPH solution ( $2.5 \mathrm{ml}$ ) and kept in the dark for $30 \mathrm{~min}$ before recording of absorbance at $517 \mathrm{~nm}$ against methanol. In the control tube, the sample was replaced by $\mathrm{MeOH}$. The inhibition of initial absorbance of the $\mathrm{DPPH}^{*}$ solution was calculated by using the formula shown below. Regression analysis was carried out by using Microsoft Excel 2007 program to calculate IC $_{50}$ (Concentration causing 50\% inhibition) value.

$$
\% \text { of Inhibition }=\left(1-\mathrm{A}_{\text {sample }} / \mathrm{A}_{\text {control }}\right) \times 100
$$

\section{Ferric reducing activity power (FRAP) assay}

The FRAP assay measures the total antioxidant activity on the basis of the ability to reduce Fe(III) to $\mathrm{Fe}(\mathrm{II})$ ions (Benzie \& Strain 1996). Working solutions of different concentrations of samples (5, 10, 15, 20, 25 $\mu \mathrm{g} / \mathrm{ml}$ in methanol $)$ and reference $\mathrm{FeSO}_{4} .7 \mathrm{H}_{2} \mathrm{O}(25,100$, 200, 300, 400 and $500 \mu \mathrm{g} / \mathrm{ml}$ in distilled water) were prepared. To each working solution $(200 \mu \mathrm{l})$ was added $2800 \mu \mathrm{l}$ of the FRAP reagent. After 4 min of incubation at $37^{\circ} \mathrm{C}$, the absorbance at $593 \mathrm{~nm}$ was measured against methanol/water $(1: 14)$ or water as a blank. The obtained data were used to calculate $\mathrm{EC}_{1}$ (Effect concentration equivalent to $1 \mathrm{mM} / \mathrm{FeSO}_{4} .7 \mathrm{H}_{2} \mathrm{O}$ ) value.

\section{Results and Discussion}

The onion bulb skin peel contains a high content of quercetin glycosides (2-10\% w/w), oxidized derivatives as well as free aglycone (Griffiths et al. 2002, Suh et al. 1999). From the onion skin, we have isolated free quercetin (1) in $0.1 \% \mathrm{w} / \mathrm{w}$. After methylation of $\mathbf{1}$, tetramethyl ether derivative (2) was yielded in 83.3\% (Scheme 1). Both the compounds were authenticated by UV-Vis and ${ }^{1} \mathrm{H}$ NMR spectra analyses. A comparable UV-Vis spectral analysis for the identification of the substitution pattern in these compounds was proved valuable and the results are summarised in Table 1. The UV-Vis spectra of compound 2 with $\mathrm{AlCl}_{3}$ and $\mathrm{AlCl}_{3} /$ $\mathrm{HCl}$ were similar with a bathochromic shift of $47 \mathrm{~nm}$ in Band I indicating the presence of a free 5-hydroxyl group. We were not surprised to obtain quercetin 3,3',4',7-tetramethyl ether (2) rather than pentamethyl ether derivative since methylation of the 5-hydroxyl group in the structural motif is known to be difficult (Looker \& Ernst 1954).

Table 1. UV-Vis spectral analyses of compounds 1 and 2

\begin{tabular}{|c|c|c|c|c|c|c|c|c|}
\hline \multirow[t]{3}{*}{ Reagent } & \multicolumn{4}{|c|}{$\begin{array}{l}\text { Querc etin } \\
\text { (1) }\end{array}$} & \multicolumn{4}{|c|}{$\begin{array}{c}\text { Quercetin 3,3',4',7-tetramethyl ether } \\
\text { (2) }\end{array}$} \\
\hline & \multicolumn{2}{|c|}{ UV Band } & \multirow{2}{*}{$\begin{array}{c}\text { Shift of } \\
\text { Band (nm) }\end{array}$} & \multirow{2}{*}{$\begin{array}{l}\text { Substitution } \\
\text { pattern }\end{array}$} & \multicolumn{2}{|c|}{ UV Band } & \multirow{2}{*}{$\begin{array}{c}\text { Shift of } \\
\text { Band (nm) }\end{array}$} & \multirow{2}{*}{$\begin{array}{c}\text { Substitution } \\
\text { pattern }\end{array}$} \\
\hline & I & II & & & I & II & & \\
\hline$(\mathrm{MeOH})$ & 372 & 255 & & & 355 & 256 & & \\
\hline$(+\mathrm{NaOAc})$ & 377 & 272 & II $(+17)$ & $7\lrcorner \mathrm{OH}$ free & 350 & 257 & II $(+1)$ & 7-OMe \\
\hline $\begin{array}{l}(+\mathrm{HaOAc} \\
\left.+\mathrm{H}_{3} \mathrm{BO}_{3}\right)\end{array}$ & 386 & 262 & $I(+14)$ & 3',4'-di $\mathrm{OH}$ free & 350 & 256 & $I(-5)$ & 3',4'-di OMe \\
\hline$\left(+\mathrm{AlCl}_{3}\right)$ & 452 & 273 & $\mathrm{I}(+80)$ & $\begin{array}{l}5-\mathrm{OH} \text { andior } \\
3 \mathrm{OH} \text { free }\end{array}$ & $\begin{array}{l}360 \\
402\end{array}$ & 272 & $I(+47)$ & $5-\mathrm{OH}$ free \\
\hline $\begin{array}{l}\left(+\mathrm{AlCl}_{3}\right. \\
+\mathrm{HCl})\end{array}$ & 429 & 271 & $I(+57)$ & $5\lrcorner \mathrm{OH}$ free & $\begin{array}{l}402 \\
408\end{array}$ & 272 & $I(+47)$ & $5-\mathrm{OH}$ free \\
\hline$(+\mathrm{HaOH})$ & 425 & 288 & $I(+53)$ & 3,4'-di $O H$ free & 374 & 284 & $I(+19)$ & 3,4'-di OMe \\
\hline
\end{tabular}


<smiles>O=c1c(O)c(-c2ccc(O)c(O)c2)oc2cc(O)cc(O)c12</smiles>

Quercetin (1)

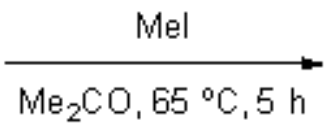

Queretin tetramethyl ether (2)

Scheme 1. Synthesis of compound 2

The compounds 1 and 2 were evaluated for áchymotrypsin inhibitory activity. Compound $\mathbf{1}$ displayed inhibitory effect with $\mathrm{IC}_{50}$ value of $88.9 \pm 2.5$ $\mathrm{ìg} / \mathrm{ml}$, whereas compound 2 showed $9.3 \%$ inhibition at $500 \mu \mathrm{M}$, thus found ineffective and therefore IC $_{50}$ was not evaluated.

The $\%$ inhibition versus concentration of compounds $\mathbf{1}$ and $\mathbf{2}$ showed a linear variance in the DPPH assay (Fig. 1). It can be clearly seen from Fig. 1 that compound 2 displayed poor DPPH free radical scavenging capacity ( $\leq 5 \%$ inhibition at $5-25 \mathrm{ì} \mathrm{g/ml} \mathrm{concentration).} \mathrm{The}$ IC $_{50}$ values calculated for compounds $\mathbf{1}$ and $\mathbf{2}$ were 14.87 and $283.61 \mathrm{ig} / \mathrm{ml}$, respectively. Since $\mathrm{IC}_{50}$ is a measure of inhibitory concentration, a lower $\mathrm{IC}_{50}$ value would reflect a greater antioxidant activity of the sample. Therefore in contrast to the parent quercetin (1), quercetin 3,3',4',7-tetramethyl ether (2) was found ineffective for the free radical scavenging potentiality.

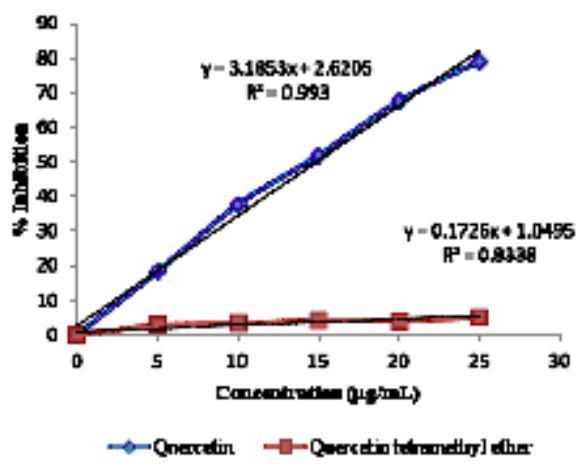

Fig. 1. The curve plotted between $\%$ inhibition versus concentration of compounds $\mathbf{1}$ and $\mathbf{2}$ in the DPPH assay.

Taking $\mathrm{FeSO}_{4} \cdot 7 \mathrm{H}_{2} \mathrm{O}$ as the reference, a standard curve of absorbance versus concentration in $\mathrm{mM} / \mathrm{l}$ was plotted in the FRAP assay (Fig. 2). The concentration of the compound (as an antioxidant) having a ferric reducing ability equivalent to that of $1 \mathrm{mM} / \mathrm{l}$ $\mathrm{FeSO}_{4} \cdot 7 \mathrm{H}_{2} \mathrm{O}$ was calculated and the values for compounds 1 and 2 were found to be 112. 94 and 389.54 ì M/l, respectively. This result clearly indicated that quercetin (1) had 3.5 folds more ferric reducing power than quercetin 3,3',4',7-tetramethyl ether (2).

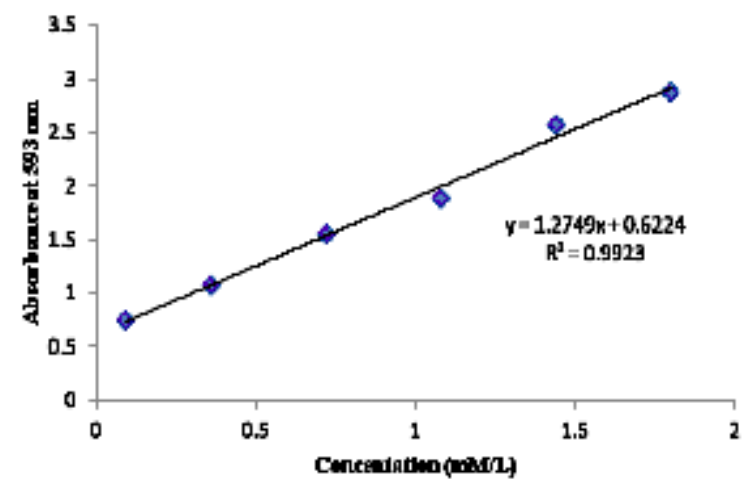

Fig. 2. Concentration-response ferrous sulphate standard curve in the FRAP assay.

In conclusion, quercetin aglycone (1) was isolated from the skin of red onion bulb and used for the methylation to afford quercetin 3,3',4',7-tetramethyl ether (2). $\alpha$-Chymotrypsin inhibition, DPPH free radical scavenging activity and ferric reducing power of $\mathbf{1}$ were found to be diminished upon using its tetramethyl ether derivative $\mathbf{2}$.

\section{Acknowledgements}

This work was supported by Nepal Academy of Science and Technology (NAST). Prof. M. I. Choudhary, Director, H.E.J. Research Institute of Chemistry, University of Karachi, Pakistan is acknowledged for providing NMR facilities. Special thank goes to Bishnu Marasini, who is pursuing Ph. D. study in the later institute, for helping us in many ways. 
G. B. Bajracharya \& D. B. Thapa/Quercetin as a Protease........

\section{References}

Benzie, I.F.F. and J.J. Strain. 1996. The ferric reducing ability of plasma (FRAP) as a measure of antioxidant power: The FRAP assay. Analytical Biochemistry 239:70-76.

Bohm, B.A. 1998. Introduction to flavonoids. Harwood Academic Publishers: Amsterdam.

Brand-Williams, W., M.E. Cuvelier and C. Berset. 1995. Use of a free radical method to evaluate antioxidant activity. LBT - Food Sci. Technol. 28:25-30.

Choudhary, M.I., A. Adhikari, S. Rasheed, B.P. Marasini, N. Hussain, W.A. Kaleem and Atta-ur-Rahman. 2011. Cyclopeptide alkaloids of Ziziphus oxyphylla Edgw as novel inhibitors of á-glucosidase enzyme and protein glycation. Phytochem. Lett. 4:404-406.

Formica, J.F. and W. Regelson. 1995. Review of the biology of quercetin and related bioflavonoids. Food Chem. Tox. 33:1061-1080.

Griffiths, G., L. Trueman, T. Crowther, B. Thomas and B. Smith. 2002. Onions - a global benefit to health. Phytother. Res. 16:603-615.

Hertog, M.G.L., P.C.H. Hollman, M.B. Katan and D. Kromhout. 1993. Estimation of daily intake of potentially anticarcinogenic flavonoids and their determinants in adults in The Netherlands. Nutr. Cancer 20:21-29.

Looker, J.H. and F. C. Ernst. 1954. A novel acetylation of quercetin 3,3'4',7-tetramethyl ether (5-hydroxy3,3',4',7-tetramethoxy flavone). J. Am. Chem. Soc. 76: 294-294.

Materska, M. 2008. Quercetin and its derivatives: Chemical structure and bioactivity - A review. Pol. J. Food Nutr. Sci. 58:407-413.
Patick, A.K. and K.E. Potts. 1998. Protease inhibitors as antiviral agents. Clinical Microbiol. Rev. 11:614-627.

Rauh, R., A. Diakov, A. Tzschoppe, J. Korbmacher, A.K. Azad, H. Cuppens, J.-J. Cassiman, J. Dötsch, H. Sticht and C. Korbmacher. 2010. A mutation of the epithelial sodium channel associated with atypical cystic fibrosis increases channel open probability and reduces $\mathrm{Na}^{+}$ self inhibition. The Journal of Physiology 588:1211-1225.

Scalbert, A. and G. Williamson. 2000. Dietary intake and bioavailability of polyphenols. J. Nutr. 130:2073-2085.

Stehlik, C. 2009. Multiple interleukin-1â-converting enzymes contribute to inflammatory arthritis. Arthritis and Rheumatism 60:3524-3530.

Suh, H.J., J.M. Lee, J.S. Cho, Y.S. Kim and S.H. Chung. 1999. Radical scavenging compounds in onion skin. Food Res. Int. 32:659-664.

Tuladhar, S.M. and G.B. Bajracharya. 1999. Potentially anticarcinogenic flavonoids in Ilam leaf tea (first flush). In: Proceedings of III national conference on science and Technology. Royal Nepal Academy of Science and Technology, Kathmandu, Nepal, pp. 1469-1476.

Walle, T. 2004. Absorption and metabolism of flavonoids. Free Rad. Biol. Med. 36:829-837.

Web1.http://www.chemicalbook.com/ ChemicalProductProperty_EN_CB8417408.htm.

Wilcox, P.E. 1970. Chymotrypsinogens-chymotrypsins. Methods in Enzymology 19:64-108.

Yoshioka, T., T. Inokuchi, S. Fujioka and Y. Kimura. 2004. Phenolic compounds and flavonoids as plant growth regulators from fruit and leaf of Vitex rotundifolia. $Z$. Naturforsch 59c:509-514. 
Nepal Journal of Science and Technology Vol. 14, No. 2 (2013) 91-96 